\title{
TELAAH HAK AKSESIBILITAS PASIEN PENYANDANG TUNANETRA TERHADAP BERKAS REKAM MEDIS DI RUMAH SAKIT
}

\author{
Achmad Jaelani Rusdi $^{1}$, Arief Efendi ${ }^{1}$, Dewi Anggraeni ${ }^{1}$, Suwito ${ }^{1}$ \\ ITSK RS dr. Soepraoen Kesdam V/Brawijaya Malang \\ (Email: achmadjaelani77@gmail.com ${ }^{1}$ )
}

\begin{abstract}
ABSTRAK
Kesenjangan infomasi bagi penderita tunanetra terjadi karena adanya keterbatasan pada indera penglihatan. Permasalahan yang ada saat ini adalah belum adanya Rumah Sakit yang menyediakan berkas rekam medis braille. Hal ini penting karena penyandang tunanetra yang menjadi pasien di suatu Rumah Sakit memiliki hak untuk mengetahui data medisnya. Penelitian ini bertujuan mengkaji secara secara yuridis aksesibilitas pasien tunanetra terhadap berkas rekam medis. Metode penelitian menggunakan pendekatan yuridis normatif dengan metode deskriptif kualitatif, dan data sekunder yang diperoleh dengan studi kepustakaan. Hak akses informasi medis dan persetujuan tindakan kedokteran merupakan hak pasien tunanetra yang termasuk kategori cakap dan kompeten berdasarkan peraturan yang berlaku, hal ini juga sesuai dengan ketentuan kerahasiaan rekam medis sehingga pasien tunanetra berhak mengakses secara langsung informasi medis di Rumah Sakit. Rumah Sakit wajib menghormati dan melindungi hak-hak pasien terkait akses informasi, persetujuan tindakan kedokteran dan kerahasiaan data medis pasien di berkas Rekam Medis sesuai dengan peraturan perundang-undangan tidak terkecuali bagi pasien tunanetra, hal ini sesuai dengan UU Penyandang Cacat dan Permenkes Persetujuan Tindakan Kedokteran.
\end{abstract}

Kata kunci: Tunanetra, Rekam Medis, Rumah Sakit.

\begin{abstract}
Introduction Information gaps for blind people occur due to limitations in the sense of sight. The problem that exists today is that there is no hospital that provides braille medical record files. This is important because blind people who are patients in a hospital have the right to know their medical data. This study aims to examine juridically the accessibility of blind patients to medical record files. The research method uses a normative juridical approach with qualitative descriptive methods, secondary data obtained by literature study and compared with statutory regulations. The right to access medical information and consent to medical action are the rights of blind patients who are categorized as competent and competent based on applicable regulations, this is also in accordance with the provisions of confidentiality of medical records so that blind patients have the right to directly access medical information at the hospital Hospitals are obliged to respect and protect the rights of patients Patients with regard to access to information, consent to medical action and confidentiality of patient medical data in Medical Record files in accordance with statutory regulations, including for visually impaired patients, this is in accordance with the Disability Law and the Minister of Health Approval of Action Medical.
\end{abstract}

Keywords: Visually impaired, Medical Record, Hospital 
Online di https://jurnal.poltekkes-soepraoen.ac.id DOI: $10.47794 /$ jkhws

PENDAHULUAN

Berdasarkan pada Undang-Undang

No. 4 Tahun 1997 tentang Penyandang

Cacat salah satu klasifikasi penyandang disabilitas adalah tunanetra. Tunanetra merupakan individu yang terhambat mobilitas aktivitas gerak yang disebabkan oleh hilang atau kurangnya sistem penglihatan sebagai akibat dari kelahiran, penyakit maupun kecelakaan. Jumlah orang yang dipengaruhi oleh penyebab umum kehilangan penglihatan telah meningkat secara substansial seiring dengan bertambahnya usia dan populasi (Flaxman dkk, 2017). Gejala yang dirasakan pasien berkurang secara visual ketajaman atau sensitivitas kontras, kehilangan bidang visual, diplopia, fotofobia, persepsi visual kesulitan atau distorsi visual (Camelia dkk., 2018).

Kesenjangan informasi bagi penderita tunanetra terjadi karena adanya keterbatasan pada indra penglihatan, sehingga kapasitas informasi yang diterima oleh tunanetra sangat minim, oleh karena itu diciptakan braille dan akses digital untuk memberikan akses informasi kepada tunanetra. Braille telah digunakan di seluruh dunia sebagai metode baca bagi penyandang tunanetra. Hal ini menjadi penting karena memberikan akses bagi mereka yang membutuhkan untuk dapat membaca seperti orang lain. Braille berupa kumpulan dari beberapa karakter yang terdiri dari titik-titik yang diangkat dalam sel untuk memungkinkan seorang tunanetra dapat membaca dan berkomunikasi (Hoshino \& Motoki, 2018). Pemahaman terhadap informasi dari data yang didapatkan pada buku atau berkas juga merupakan hak dari penyandang tunanetra. Tidak terkecuali dengan data medis yang mereka miliki di sarana pelayanan kesehatan. Data medis yang tertulis dalam rekam medis pasien merupakan tanggung jawab penyedia sarana pelayanan kesehatan merupakan hak kerahasiaan informasi medis pasien (Rusdi, 2019), sedangkan Rumah Sakit sebagai sarana pelayanan kesehatan bertugas menjaga data tersebut baik dalam hal fisik maupun kerahasiaannya, hal ini telah diatur dalam Permenkes nomor 269 tahun 2008 tentang rekam medis.

Terkait kerahasiaan rekam medis ersebut, dalam buku Manual Rekam Medis (Konsil Kedokteran Indonesia, 2006) menyatakan setiap dokter atau dokter gigi dalam melaksanakan praktik kedokteran wajib menyimpan kerahasiaan yang menyangkut riwayat penyakit pasien yang tertuang dalam rekam medis. Rahasia kedokteran tersebut dapat dibuka hanya untuk kepentingan pasien untuk memenuhi 
permintaan aparat penegak hukum (hakim majelis), permintaan pasien sendiri atau berdasarkan ketentuan perundangundangan yang berlaku. Berdasarkan hal tersebut jika berkas rekam medis dibutuhkan atas permintaan pasien sendiri, maka Rumah Sakit seyogyanya memberikan akses informasi medis khususnya bagi pasien tunanetra dengan kode braille atau digitial yang memungkin pasien dapat mengetahui sendiri informasi medisnya atau dapat memberikan persetujuan tindakan medis yang akan diterimanya tanpa melalui perantara, mengingat akan kerahasiaan informasi medis tersebut.

Permasalahan yang ada saat ini adalah belum adanya Rumah Sakit yang menyediakan berkas rekam medis braille. Hal ini penting karena penyandang tunanetra yang menjadi pasien di suatu Rumah Sakit memiliki hak untuk mengetahui data medisnya, akan tetapi karena faktor kerahasiaan yang dimiliki data medis tersebut, seharusnya pasien dapat membaca sendiri rekam medis miliknya, tanpa harus dengan perantara petugas maupun keluarga pasien. Selama ini di Rumah Sakit hanya menggunakan rekam medis secara manual sehingga apabila ada pasien tunanetra yang membutuhkan informasi medis maka pemberian informasi berkas rekam medisnya dengan adanya perantara oleh pengantar pasien tersebut, atau pemberian informasi melalui lisan langsung kepada pasien.

Berdasarkan kesenjangan tersebut perlu adanya kajian yuridis terkait aksesibilitas pasien penyandang tunanetra terhadap berkas rekam medis di Rumah Sakit guna memberikan informasi medis sebagai hak pasien dan juga sebagai hak penyandang tunanetra sesuai dengan ketentuan perundang-undangan yang berlaku di Indonesia.

\section{METODE PENELITIAN}

Metode pendekatan yang digunakan dalam penelitian ini adalah pendekatan yuridis normatif yaitu untuk menganalisis lebih jauh mengenai hak aksesibilitas pasien penyandang tunanetra terhadap berkas rekam medis di rumah sakit dengan peraturan yang berlaku. Kajian ini ditinjau dengan metode penelitian deskriptif kualitatif. Spesifikasi penelitian ini adalah bertujuan menggambarkan secara sistematik, akurat fakta dan karakteristik mengenai populasi atau mengenai bidang tertentu, selain itu penelitian ini juga berusaha menggambarkan situasi dan kejadian (Saifuddin, 2004). Sumber data yang digunakan dalam penelitian ini adalah data sekunder dengan metode pengumpulannya adalah studi kepustakaan. 


\section{HASIL DAN PEMBAHASAN}

\section{Hak informasi medis pasien}

Pasien merupakan pemilik isi dari rekam medis, sedangkan Rumah Sakit bertanggung jawab sepenuhnya dalam menjaga berkas rekam medis baik fisik maupun kerahasiaan yang ada di dalamnya. Dalam hal ini pasien berhak mendapatkan informasi terkait dengan keadaan penyakit dan pelayanan kesehatan yang didapatkan selama di Rumah Sakit, risiko dari dilakukan maupun tidak dilakukan dari pelayanan yang diberikan di Rumah Sakit tersebut (Siringoringo, 2017). Hal ini penting untuk dipahami langsung oleh pasien, sehingga jika suatu hari pasien menderita suatu penyakit atau keadaan tertentu yang dimungkinkan diakibatkan oleh penyakit atau tindakan medis yang pernah didapatkan, maka informasi tersebut dapat ditemukan pada data klinis dalam berkas rekam medis di sarana pelayanan kesehatan yang telah memberikan pelayanan kepada pasien tersebut.

Data klinis merupakan data medis yang didapatkan dari hasil pemeriksaan, pengobatan, perawatan dan tindakan yang dilakukan tenaga kesehatan dan penunjang medis terhadap pasien. Dari runtutan "cerita" dalam lembar-lembar yang berisi data klinis inilah dapat diambil informasi untuk berbagai kebutuhan, terutama berkaitan langsung dengan pelayanan terhadap pasien (Triyanti \& Weningsih, 2018).

Berdasarkan hal tersebut maka Rumah Sakit wajib menghormati dan melindungi hak-hak pasien sebagaimana dimaksud dalam Undang-Undang Nomor 69 Tahun 2014 tentang Kewajiban Rumah Sakit dan Kewajiban Pasien. Setidaknya ada empat poin terkait kerahasiaan informasi medis pasien khususnya bagi pasien tunanetra, yaitu (1) mendapatkan informasi yang meliputi diagnosis dan tata cara tindakan medis, tujuan tindakan medis, alternatif tindakan, risiko dan komplikasi yang mungkin terjadi, dan prognosis terhadap tindakan yang dilakukan sertya perkiraan biaya pengobatan, (2) memberikan persetujuan atau menolak atas tindakan yang akan dilakukan oleh Tenaga Kesehatan terhadap penyakit yang dideritanya, mendapatkan perlindungan atas rahasia kedokteran termasuk kerahasiaan rekam medik dan (4) mendapatkan akses terhadap isi rekam medis. Berdasarkan pada hak pasien tersebut, pasien tunanetra juga memiliki hak yang sama terkait informasi medisnya pada berkas rekam medis. 


\section{Persetujuan dalam rekam Medis}

Persetujuan tindakan kedokteran merupakan hasil dari komunikasi yang efektif antara pasien dan dokter terkait rencana tindakan yang diajukan oleh dokter atau dokter gigi, setelah sebelumnya dijelaskan informasi yang cukup untuk dapat membuat persetujuan (Konsil kedokteran Indonesia, 2006). Persetujuan dalam lembar informed consent di berkas rekam merupakan pernyataan sepihak dari pasien, dan harus benar-benar dimengerti terkait apa saja yang tertulis dalam lembar tersebut.

Persetujuan medis dapat diberikan secara tertulis maupun lisan berdasarkan pada Permenkes Nomor 290 Tahun 2008 tentang Persetujuan Tindakan Kedokteran, lebih lanjut persetujuan tersebut dianggap sah apabila pasien telah diberi penjelasan atau informasi terkait persetujuan dengan sejelas-jelasnya, juga pasien atau yang sah mewakilinya dalam keadaan cakap (kompeten) untuk menerima informasi dan memberikan keputusan/persetujuan. Berdasarkan pada Permenkes Persetujuan Tindakan Kedokteran, pasien atau yang sah mewakili dalam keadaan cakap atau kompeten memiliki arti yang luas dan bisa menjadi kesalahan pemaknaan.

Cakap dan kompeten dalam peraturan tersebut bisa meliputi anak yang belum cukup umur sesuai dengan peraturan yang berlaku, kehilangan kesadaran atau pasien dengan gangguan jiwa, namun penyandang cacat merupakan individu yang cakap untuk mendapatkan informasi dan memberikan persetujuan dengan dibantu oleh fasilitas dan akses yang memadai. Sebagai contoh pasien tunanetra dapat memahami dengan baik informasi medis yang ia miliki serta memberikan persetujuan dengan kompeten jika tersedia kode braille pada berkas rekam medis.

\section{Kerahasiaan Rekam Medis}

Berkas rekam medis memiliki informasi milik pasien yang sangat penting dan harus dijaga kerahasiaannya berdasarkan pada Permenkes Rekam Medis. Hal ini juga diperkuat Undangundang Nomor 44 Tahun 2009 tentang Rumah Sakit yang menyatakan tanggung jawab Rumah Sakit dalam menjaga berkas rekam medis terhadap pihak yang tidak berkepentingan kecuali dengan surat permohonan pelepasan informasi medis pasien oleh pihak pengadilan dan atau pihak lain yang telah ditetapkan dalam hukum di Indonesia

Berdasarkan Undang-Undang Nomor 29 Tahun 2004 tentang Praktik Kedokteran dituliskan ketentuan terkait kerahasiaan rekam medis pada Pasal 48 ayat 1, yaitu (1) Setiap dokter atau dokter gigi dalam melaksanakan praktik kedokteran wajib menyimpan rahasia kedokteran. (2) Rahasia kedokteran dapat dibuka hanya untuk kepentingan kesehatan pasien, penegakkan hukum, permintaan 
Jurnal Kesehatan Hesti Wira Sakti

ISSN 2302-4283 (print)

ISSN 2580-9571 (online)

Online di https://jurnal.poltekkes-soepraoen.ac.id

DOI: $10.47794 / \mathrm{jkhws}$

pasien sendiri atau berdasarkan ketentuan

perundang-undangan.

Konsep kerahasiaan rekam medis

jika dianalisis akan banyak ditemukan pengecualian, fokus dalam hal ini adalah bagi siapa dan bagaimana rekam medis itu dibuka kerahasiaannya sebagaimana yang tertulis dalam Permenkes Rekam Medis. Kerahasiaan rekam medis difokuskan karena merupakan hubungan yang khusus antara dokter dan pasien yang dilindungi oleh kode etik kedokteran dan peraturan perundang-undangan. Pada dasarnya terdapat 2 kategori informasi rekam medis (Depkes RI, 2006) (1) Informasi yang mengandung nilai kerahasiaan merupakan laporan atau catatan yang terdapat dalam berkas rekam medis sebagai hasil pemeriksaan, pengobatan, observasi atau wawancara dengan pasien, (2) Informasi yang tidak mengandung nilai kerahasiaan adalah perihal identitas (nama, alamat dan lain-lain) serta informasi lain yang tidak mengandung nilai medis. Pada umumnya informasi ini terdapat dalam lembar data diri pasien, selain itu juga terdapat pada ringkasan masuk dan keluar pasien, akan tetapi pada lembaran tersebut juga terdapat informasi medis pasien yang bersifat rahasia.

\section{Aksesibilitas penyandang tunanetra terhadap rekam medis}

Undang-Undang Penyandang

Cacat menetapkan aksesibilitas terhadap penyandang cacat yaitu sebagai kemudahan yang disediakan bagi individu penyandang cacat dan lansia dalam rangka memberikan akses guna memampukan penyandang cacat untuk mandiri dan berpartisipasi aktif dalam berbagai aspek dalam hidup bermasyarakat dan bernegara. Adapun salah satu aspek aksesibilitas penyandang cacat yang wajib dipedomani oleh pemangku kebijakan yaitu akses terhadap informasi dan komunikasi serta fasilitas dan pelayanan lainnya yang bersifat terbuka seperti pada pelayanan kesehatan yaitu Rumah Sakit. Akses informasi dan komunikasi ini terutama pada data dan persetujuan medis yang diberikan kepada pasien terutama penyandang tunanetra. Berdasarkan hal itu maka perlu tersedianya tanda-tanda baca dalam tulisan braille dalam berkas rekam medis yang dapat dengan mudah dimengerti oleh pasien itu sendiri.

Akses pasien terhadap berkas rekam medis merupakan hak yang harus dijamin oleh pihak Rumah Sakit. Hal ini telah dituliskan pada lembar hak dan kewajiban pasien di setiap berkas rekam medis dengan landasan hukum Undang- 
Undang Rumah Sakit, Undang-Undang tentang Praktik Kedokteran yang kemudian mengenai pelaksanaannya diatur lebih lanjut dalam Permenkes Rekam Medis. namun dalam hal ini hak aksesibilitas berkas rekam medis hanya bersifat umum dan tidak difokuskan kepada penyandang tunanetra.

Berdasarkan hal tersebut maka aksesibilitas berkas rekam medis bagi penyandang tunanetra di Indonesia belum terselenggara sesuai dengan UU Penyandang Cacat. Hal ini dikarenakan berkas rekam medis yang digunakan di Rumah Sakit belum menyediakan fasilitas kode braille atau akses digital yang dapat dimengerti oleh pasien tunanetra, sehingga pasien tersebut dapat dengan kompeten menerima informasi dan memberikan persetujuan medis di Rumah Sakit. Mengingat kerahasiaan informasi medis yang diberikan kepada pasien itu sendiri, maka aksesibilitas pasien tunanetra terhadap berkas rekam medis secara langsung sangat penting sesuai dengan peraturan perundang-undangan untuk menjamin hak pasien yaitu akses informasi dan terlindungnya data klinis pada berkas rekam medis pasien di Rumah Sakit

\section{KESIMPULAN}

Rumah Sakit wajib menghormati dan melindungi hak-hak pasien Pasien terkait akses informasi, persetujuan tindakan kedokteran dan kerahasiaan data medis pasien di berkas Rekam Medis sesuai dengan peraturan perundangundangan. Aksesibilitas informasi berkas rekam medis juga harus bersifat universal, yaitu setiap individu berhak mengakses berkas rekam medisnya sendiri, tidak terkecuali bagi pasien tunanetra, hal ini sesuai dengan UU Penyandang Cacat dan Permenkes Persetujuan Tindakan Kedokteran, karena pasien tunanetra merupakan individu yang cakap dan kompeten untuk mendapatkan informasi dan memberikan persetujuan dengan dibantu oleh fasilitas dan akses yang memadai seperti kode braille atau akses digital pada berkas rekam medis.

Pada akhirnya telaah Telaah Hak Aksesibilitas Pasien Penyandang Tunanetra terhadap Berkas Rekam Medis di Rumah Sakit hanya terbatas pada kajian yuridis terhadap fenomena yang ada, diharapkan dalam penelitian selanjutnya dapat dirancang berkas rekam medis braille guna memfasilitasi pasien tunanetra untuk mendapatkan haknya mengakses berkas rekam medis.

\section{DAFTAR PUSTAKA}

Camelia, B. dkk. 2018. Medical and legal point of view for low-vision patients. Romanian Journal of Ophthalmology. Volume 62, Issue 1, January-March 2018. pp:48-53. doi:10.22336/rjo.2018.7 
Online di https://jurnal.poltekkes-soepraoen.ac.id DOI: $10.47794 / \mathrm{jkhws}$

Depkes RI. 2006. Buku Pedoman Penyelenggaraan Rekam Medis Rumah Sakit di Indonesia. Jakarta: Depkes RI

Flaxman dkk. 2017. Global causes of blindness and distance vision impairment 1990-2020: a systematic review and metaanalysis. The Lancet Global Health Journal Volume 5 Issue 12 E1221E1234, DECEMBER 01, 2017 DOI:https://doi.org/10.1016/S2214 $-109 X(17) 30393-5$

Hoshino, Y. and Motoki, A., 2018. An Evaluation of the Displaying Method on the Braille Learning System for the Sighted: For Understanding of the Mirror Image Relation. In International Conference on Computers Helping People with Special Needs (pp. 117- 121). Springer, Cham.

Kemenkes RI. 2008. Peraturan Menteri Kesehatan Republik Indonesia Nomor 269 Tahun 2008 tentang Rekam medis. Jakarta: Kementerian Kesehatan

Kemenkes RI. 2008. Peraturan Menteri Kesehatan Republik Indonesia Nomor 290 Tahun 2008 tentang Persetujuan Tindakan Kedokteran. Jakarta: Kementerian Kesehatan

Kemenkes RI. 2014. Peraturan Menteri Kesehatan Republik Indonesia Nomor 69 Tahun 2014 tentang Kewajiban Rumah Sakit dan Kewajiban Pasien. Jakarta:

Kementerian Kesehatan

Konsil Kedokteran Indonesia. 2006. Manual rekam Medis. Jakarta: Konsil Kedokteran Indonesia
Rusdi, A J dkk. 2019. Analisis Yuridis Manajemen Kerahasiaan Visum Et Repertum Tindak Pidana Kesusilaan di Rumah sakit Bhayangkara bondowoso. Universitas Jember Multidiciplinary Journal, Volume 2, Nomor 1, Juli 2019

Saifuddin, A., 2004. Metode Penelitian, Yogyakarta: Pustaka Pelajar

Siringoringo, V. M. P., dkk. 2017. Pengaturan Perlindungan Hukum Hak-Hak Pasien dalam Peraturan Perundang-undangan tentang Kesehatan di Indonesia. Diponegoro Law Journal. Volume 6, Nomor 2, Tahun 2017

Triyanti E. \& Weningsih, I R. 2018. Bahan Ajar Rekam Medis dan Informasi Kesehatan: Manajemen Informasi Kesehatan III Desain Formulir. Jakarta: Kementerian Kesehatan Republik Indonesia, Pusat Pendidikan Sumber Daya Manusia Kesehatan

Undang-Undang Republik Indonesia Nomor 04 Tahun 1997 tentang Penyandang Cacat.

Undang-Undang Republik Indonesia Nomor 29 Tahun 2004 tentang Praktik Kedokteran.

Undang-Undang Republik Indonesia Nomor 44 Tahun 2009 tentang Rumah Sakit.

Undang-Undang Republik Indonesia Nomor 69 Tahun 2014 tentang Kewajiban Rumah Sakit dan Kewajiban Pasien. 